Article

\title{
Cyperus laevigatus L. Enhances Diesel Oil Remediation in Synergism with Bacterial Inoculation in Floating Treatment Wetlands
}

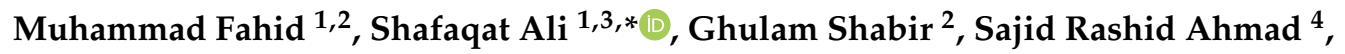

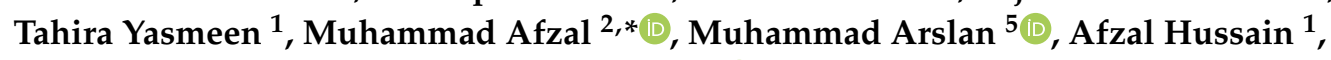 \\ Abeer Hashem ${ }^{6,7}$, Elsayed Fathi Abd Allah ${ }^{8} \mathbb{C}$, Mohammed Nasser Alyemeni ${ }^{6}$ \\ and Parvaiz Ahmad 6,9 (D) \\ 1 Department of Environmental Sciences and Engineering, Government College University Faisalabad, \\ Faisalabad 38000, Pakistan; fahadceespu@gmail.com (M.F.); rida_akash@hotmail.com (T.Y.); \\ afzaalh345@gmail.com (A.H.) \\ 2 Soil and Environmental Biotechnology Division, National Institute for Biotechnology and Genetic \\ Engineering (NIBGE), Faisalabad 38000, Pakistan; gshabirnibge@yahoo.com \\ 3 Department of Biological Sciences and Technology, China Medical University, Taichung 40402, Taiwan \\ 4 Colleges of Earth and Environmental Sciences, University of the Punjab, Lahore 54000, Pakistan; \\ sajidpu@yahoo.com \\ 5 Department of Civil and Environmental Engineering, University of Alberta, \\ Edmonton, AB T6G 2R3, Canada; marslan@ualberta.ca \\ 6 Botany and Microbiology Department, College of Science, King Saud University, P.O. Box. 2460, \\ Riyadh 11451, Saudi Arabia; habeer@ksu.edu.sa (A.H.); mnalyemeni@gmail.com (M.N.A.); \\ parvaizbot@yahoo.com (P.A.) \\ 7 Mycology and Plant Disease Survey Department, Plant Pathology Research Institute, ARC, Giza 12511, Egypt \\ 8 Plant Production Department, College of Food and Agricultural Sciences, King Saud University, \\ P.O. Box. 2460, Riyadh 11451, Saudi Arabia; eabdallah@ksu.edu.sa \\ 9 Department of Botany, S.P. College, Kothi Bagh, Srinagar, Jammu and Kashmir 190001, India \\ * Correspondence: shafaqataligill@yahoo.com (S.A.); manibge@yahoo.com (M.A.)
}

Received: 20 January 2020; Accepted: 3 March 2020; Published: 18 March 2020

check for updates

\begin{abstract}
Diesel oil is considered a very hazardous fuel due to its adverse effect on the aquatic ecosystem, so its remediation has become the focus of much attention. Taking this into consideration, the current study was conducted to explore the synergistic applications of both plant and bacteria for cleaning up of diesel oil contaminated water. We examined that the application of floating treatment wetlands (FTWs) is an economical and superlative choice for the treatment of diesel oil contaminated water. In this study, a pilot scale floating treatment wetlands system having diesel oil contaminated water $(1 \% \mathrm{w} / \mathrm{v})$, was adopted using Cyperus laevigatus $\mathrm{L}$ and a mixture of hydrocarbons degrading bacterial strains; viz., Acinetobacter sp.61KJ620863, Bacillus megaterium 65 KF478214, and Acinetobacter sp.82 KF478231. It was observed that consortium of hydrocarbons degrading bacteria improved the remediation of diesel oil in combination with Cyperus laevigatus L. Moreover, the performance of the FTWs was enhanced by colonization of bacterial strains in the root and shoot of Cyperus laevigatus L. Independently, the bacterial consortium and Cyperus laevigatus L exhibited $37.46 \%$ and $56.57 \%$ reduction in diesel oil, respectively, while $73.48 \%$ reduction in hydrocarbons was exhibited by the joint application of both plant and bacteria in FTWs. Furthermore, microbial inoculation improved the fresh biomass (11.62\%), dry biomass (33.33\%), and height (18.05\%) of plants. Fish toxicity assay evaluated the effectiveness of FTWs by showing the extent of improvement in the water quality to a level that became safe for living organisms. The study therefore concluded that Cyperus laevigatus L augmented with hydrocarbons degrading bacterial consortium exhibited a remarkable ability to decontaminate the diesel oil from water and could enhance the FTWs performance.
\end{abstract}


Keywords: floating treatment wetlands; Cyperus laevigatus L; diesel oil; plant-bacteria synergism; toxicity

\section{Introduction}

Discharge of petroleum hydrocarbons into the environment whether unintentionally or due to anthropogenic sources is the main cause of surface water and ground water pollution. Because of this alarming situation and the hazardous effect of hydrocarbons on the aquatic ecosystem, much attention is being focused on the remediation of hydrocarbons [1]. Moreover, during the petroleum refining process, raw crude oil is converted into various useful end products such as gasoline, diesel fuel, kerosene, and fuel oils. Purification of crude oil utilizes huge volumes of water which causes the generation of wastewater enriched with toxic organic compounds [2,3]. Treatment of such wastewater is very essential to achieve safe environmental water quality standards before discharge into any water body $[4,5]$. Traditional wastewater treatment processes such as electrochemical oxidation, membrane filtration, coagulation, flocculation [6,7] require highly skilled man power and high operational and maintenance costs. Moreover, application of these techniques generates toxic waste that further needs treatment before disposal $[8,9]$.

It has been reported by many studies that various types of domestic and industrial wastewaters are widely treated using floating treatment wetlands [10-14]. This innovative technology has low installation, operational and maintenance costs, along with aesthetic value and environmentally friendly quality $[15,16]$. In floating treatment wetlands, plants are grown on a floating mat, whereas roots are hanged in the water column [17]. The extended roots in the water body offer plants the ability to create a direct contact between contaminants and the roots-associated microbial community. In addition, the suspended roots in water accelerate the sedimentation process by trapping suspended particles and reducing the water turbulence [18]. The roots grow horizontally and vertically to provide a large surface area for nutrient uptake and biofilm enlargement [13]. The associated microbial community degrades complex organic matter into simple components which are removed through the combined action of plants and microbes $[19,20]$. Floating treatment wetlands in assistance with bacterial consortium can be a promising alternative and green technology for remediation of oil refinery effluent. Many bacterial genera have been reported to degrade the hydrocarbons by their metabolic process [21]. Bacteria enhance the solubility, bioavailability, biodegradation, and uptake of hydrophobic compounds by production of biosurfactants which also facilitate microbial growth and hydrocarbon emulsification [22]. Plants provide nutrients, metabolites, phyto-hormones, and habitat for bacteria [23]. In FTWs, the plants augmented with hydrocarbon degrading bacteria could be an effective methodology for the remediation of diesel oil from water. Floating treatment wetlands augmented with Cyperus laevigatus $\mathrm{L}$ and hydrocarbon-degrading bacteria have not been widely tested for treatment of water polluted by diesel oil. So, considering this, the current study was undertaken with the main objective to assess the synergistic potential of Cyperus laevigatus $\mathrm{L}$ and hydrocarbons degrading bacterial strains in the FTWs system to remediate diesel oil from water.

\section{Methodology}

\subsection{Diesel Oil}

The diesel oil used in this study was purchased from a local filling station. The diesel oil was filter sterilized via syringe filters and was used as such without any further analysis for detail composition of the entire compounds. 


\subsection{Preparation of Mixed Bacterial Culture}

Three hydrocarbons degrading bacterial strains viz.; Acinetobacter sp.61KJ620863, Bacillus megaterium 65 KF478214, and Acinetobacter sp. 82 KF478231 already isolated and characterized [24] were applied in the current experiment. All the hydrocarbons degrading bacterial strains were grown separately in M9 solution containing diesel oil 1\% (w/v) as a sole carbon source. After growth in M9 solution, the bacterial culture was centrifuged then resuspended in normal saline solution. To achieve $10^{8}$ cells $\mathrm{mL}^{-1}$, the optical density of each microbial suspension was adjusted finally using normal saline solution. The bacterial suspension was spread on the LB agar plates to count the number of colonies. The cell suspension of each bacterial strain was mixed in equal proportion and the consortium $(50 \mathrm{~mL})$ was inoculated in FTWs microcosms.

\subsection{Manufacturing of Floating Treatment Wetlands}

The FTWs were fabricated at the National Institute for Biotechnology and Genetic Engineering, (NIBGE) Faisalabad Pakistan. The experiment was conducted for 90 days beginning in the month of April 2018. In the FTWs microcosms, the tanks having $20 \mathrm{~L}$ volume capacity were made of poly ethylene material, whereas the floating mats were preapared using Jumbolon sheets of Diamond Foam Company, Pvt. Ltd., Pakistan. The Jumbolon foam piece, which was used as a floating mat, comprises the dimension of $50.8 \mathrm{~cm}$ (length) $\times 38.1 \mathrm{~cm}$ (width) $\times 7.62 \mathrm{~cm}$ (thickness) and five holes in each mat which were drilled at equal distance for growing healthy seedlings of Cyperus laevigatus $\mathrm{L}$.

The seedlings of selected plant were allowed to grow for thirty days duration in the FTWs microcosms containing tap water without any treatment. However, Hoagland solution was applied periodically to stabilize the process of root-establishment. After thirty days acclimatization of plant roots, the outer surface of roots was sterilized using $5 \% \mathrm{NaOCl}$ (sodium hypochlorite) solution. The established microcosms were spiked with $1 \%$ diesel oil $(\mathrm{w} / \mathrm{v})$. The concentration of diesel oil was selected based on our previous studies of diesel oil biodegradation $(0.5 \%, 1.0 \%$, and $1.5 \%$ diesel oil) in M9 media by shake flask experimentation.

\subsection{Experimental Design}

The experimental setup of floating treatment wetlands is shown in Figure 1. The floating treatment wetland microcosms were prepared in triplicates and different types of treatments were as follows:

Control-1 (C1): Microcosm consist of diesel oil polluted water and no plants.

Control-2 (C2): Microcosm consist of tap water and plants.

Treatment-1 (T1): Microcosm consist of diesel oil polluted water and bacterial consortium.

Treatment-2 (T2): Microcosm consist of diesel oil polluted water and plants.

Treatment-3 (T3): Microcosm consist of diesel oil polluted water, plants, and bacterial consortium. 


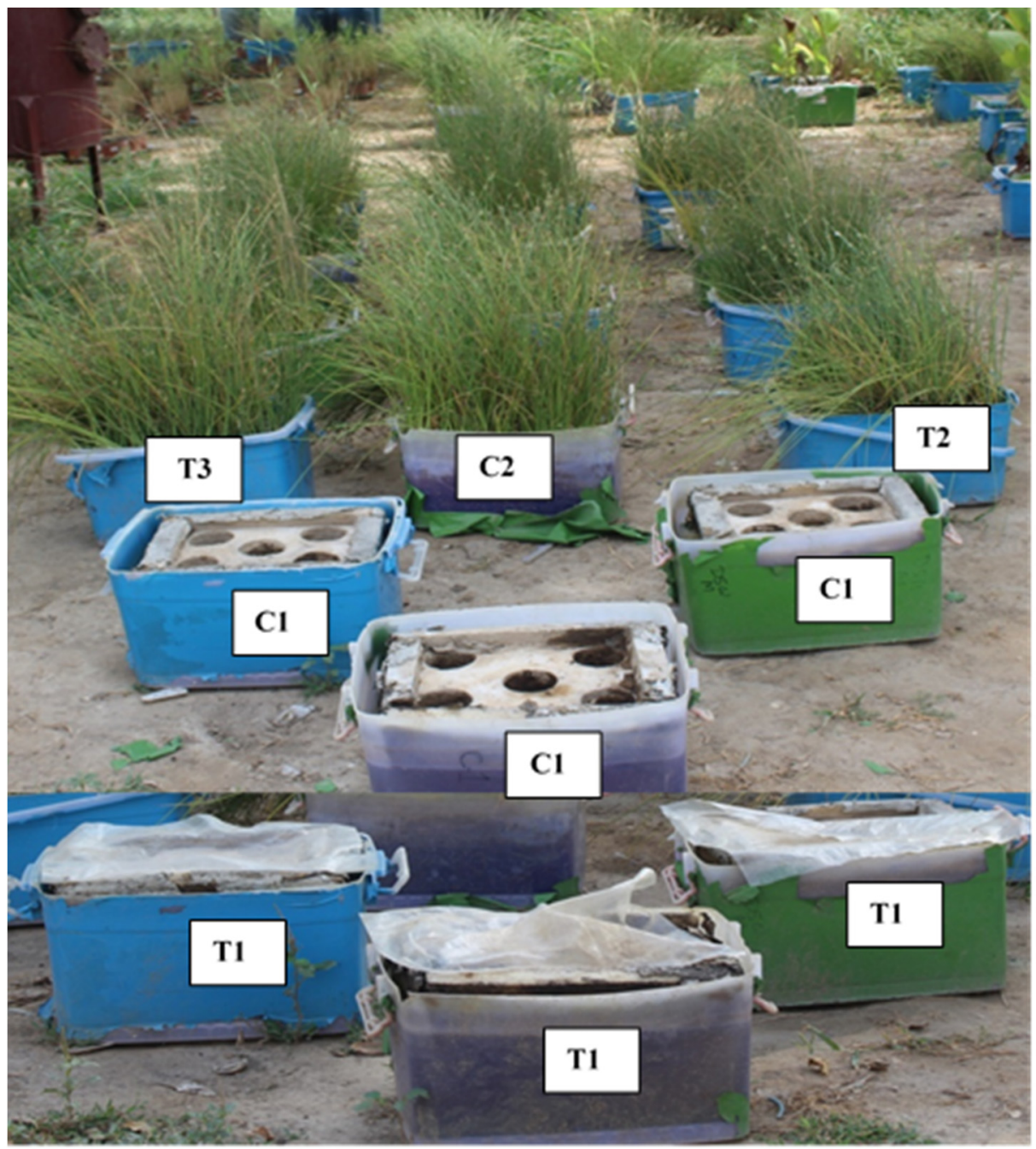

Figure 1. Experimental setup showing the floating treatment wetlands system for the cleanup of diesel oil polluted water.

\subsection{Plant Biomass}

After 3 months of the experimental period, the plant roots and shoots were cropped $2 \mathrm{~cm}$ down and overhead the floating mat. For both roots and shoots, the fresh and dry biomass was determined to check the influence of microbial inoculation and plant growth on diesel oil remediation. Fresh roots and shoots samples were placed in an oven at $70{ }^{\circ} \mathrm{C}$ and dry biomass was determined [25].

\subsection{Hydrocarbons Assessment}

The residual amount of hydrocarbons present in the treated water sample was extracted as an extracting solvent using the organochloride compound dichloromethane. Briefly, water sample having amount $25 \mathrm{ml}$ was shaken with $15 \mathrm{~mL}$ of dichloromethane in a glass separatory funnel for $15 \mathrm{~min}$. After $30 \mathrm{sec}$ agitation and $3 \mathrm{~min}$ settling time, the water layer was discarded. The procedure was repeated thrice until the entire water sample was completely extracted. The obtained extract was dried using $5 \mathrm{~g}$ anhydrous sodium sulphate. The extract was then transferred to a Teflon-capped glass tube. The extracted hydrocarbons were analyzed by Spectrum Two Fourier transform infrared (FTIR) spectrometer [26]. 


\subsection{Water Quality Parameter Analyses}

Water samples were collected at different time intervals. These water samples were tested for $\mathrm{pH}$, electrical conductivity (EC), dissolved oxygen (DO), total suspended solids (TSS), total solids (TS), total dissolved solids (TDS), chemical oxygen demand (COD), biochemical oxygen demand (BOD), and total organic carbon (TOC) using established standard protocols [27].

\subsection{Persistence of Bacterial Culture}

Treated water, roots, and shoots samples collected at different time intervals were analyzed for the survival of the hydrocarbons degrading bacteria in water, plant rhizosphere, and endosphere by plate count method. By following the established protocols, the surface sterilization was applied to the roots and shoots for the isolation of endophytic bacteria [28]. Briefly, plant roots and shoots samples were washed by using autoclaved distilled water, followed by ethanol (70\%) and sodium hypochlorite solution ( $2 \%)$. Finally, the roots and shoots samples were also wash away with autoclaved distilled water. The surface sterilized roots and shoots were ground $(5 \mathrm{~g})$ by using pestle and mortar and were mixed using $10 \mathrm{~mL} \mathrm{NaCl}$ solution $(0.9 \% \mathrm{w} / \mathrm{v})$ to make a suspension. The suspension was serially diluted up to $10^{-6}$. A $100 \mu \mathrm{L}$ of the suspension was spread on the M9 agar media containing diesel oil $(50 \mathrm{mg} / \mathrm{L})$ as a sole carbon source by spreading plate methodology. For the determination of total hydrocarbons degrading bacteria, the petri dishes were incubated at $37^{\circ} \mathrm{C}$ for $48 \mathrm{~h}$.

\subsection{Evaluation of Toxicity}

After the completion of the experimentation, the treated water samples were tested for toxicity using fish toxicity assay. Glass tanks were filled with treated water from each treatment. In each tank, ten fish Labeo rohita of equal size and weight were added. The fish toxicity experiment was conducted for a duration of $96 \mathrm{~h}$. After every $24 \mathrm{~h}$ of regular interval, the number of fish survival was recorded $[29,30]$.

\subsection{Statistical Analyses}

Water pollution parameters, residual hydrocarbon concentration, perseverance of hydrocarbons degrading bacteria in water, root and shoot, plant biomass, and reduction in toxicity level were analyzed through Statistics 8.1. Factorial Analysis of Variance (ANOVA) to make the comparison between independent variable. Further all pairwise comparisons between time into treatments were analyzed by Tukey HSD $(\alpha=0.05)$. The alphabets on values represent the significant/non-significant difference among the treatments.

\section{Results and Discussion}

\subsection{Hydrocarbons Degradation}

Discharges of petroleum oil during transportation of oil tankers, refining of crude oil, and leakage in underground storage tanks is the main cause of environmental contamination and ultimately damage of the ecosystem [31]. Diesel oil has been widely reported as a very harmful petroleum product that is composed of a complex mixture of hydrocarbons. These hydrocarbons pose severe threats to human health due to their mutagenic, carcinogenic, and immune toxic behavior [32]. Consequently, serious attention has been focused on remediating the adverse effect of hydrocarbons on the water quality. Figure 2 shows gradual reduction of hydrocarbons concentrations in diesel oil contaminated water during the 90 day experiment under different treatments. It was noticed that in $\mathrm{T} 3$ treatment consisting of Cyperus laevigatus L and bacterial consortium, the removal of hydrocarbons in FTWs microcosms was maximum (73.48\%). It may be due to the combined effect of both plant and hydrocarbon bacteria. It has been reported that in the presence of the microorganism, plants get enough support in severe conditions and can perform better organic pollutant degradation [33,34]. It has also been noted that 
the root exudates secreted by the plant, boost up the growth and activity of rhizosphere bacterial communities [35].

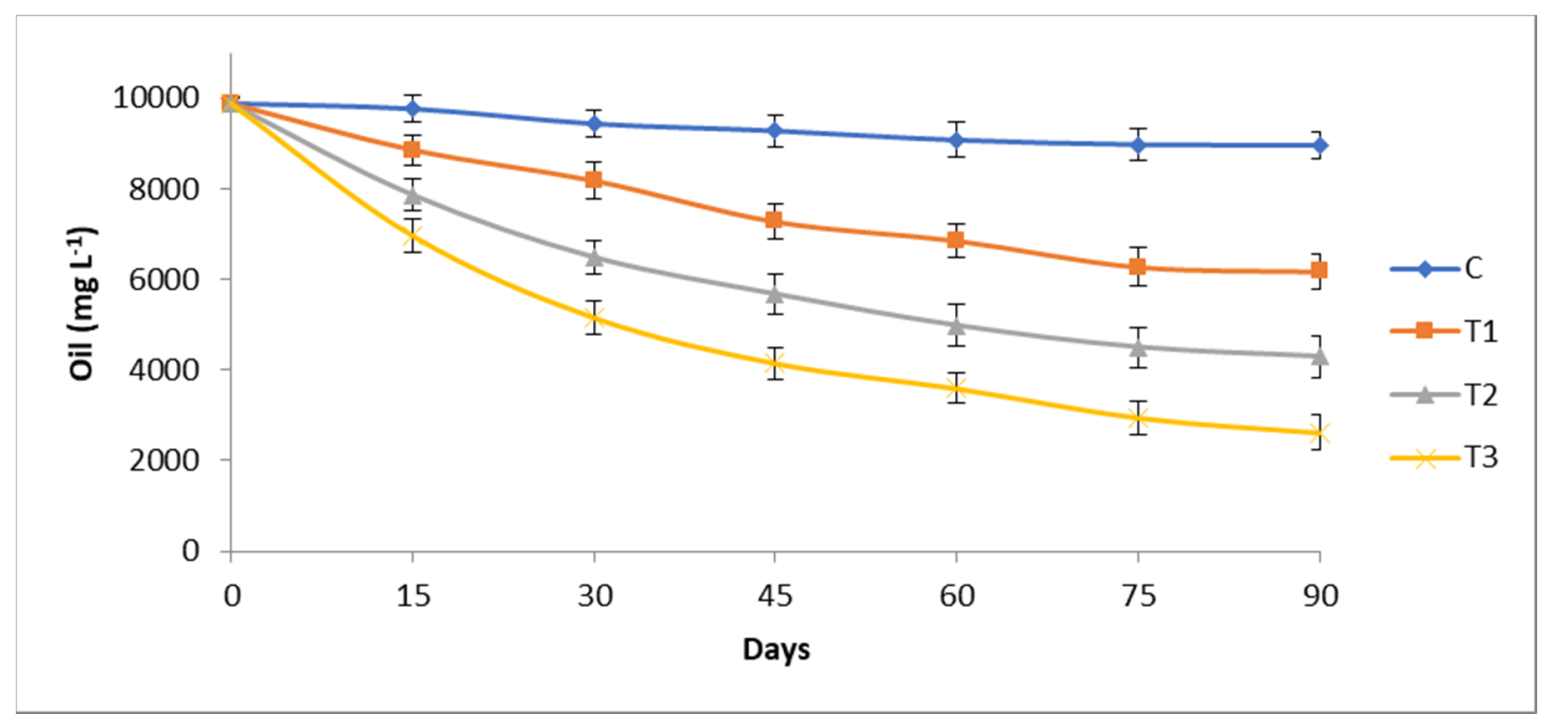

Figure 2. Diesel oil removal from water by floating treatment wetlands. C: Microcosm containing diesel oil polluted water and no plants; T1: Microcosm containing diesel oil polluted water and bacterial consortium; T2: Microcosm containing diesel oil polluted water and plants; T3: Microcosm containing diesel oil polluted water, plants and bacterial consortium. Each value is a mean of triplicate determination. Error bars represent the standard deviations among all three replicates.

In un-vegetated treatment with bacterial consortium (T1), only $37.46 \%$ reduction of hydrocarbons was observed. It has been described that bacterial populations have the tendency to mineralize hydrocarbons present in diesel oil [36]. However, it was observed that in T1 treatment, hydrocarbon reduction was 2 times lower than $\mathrm{T} 3$ treatment. It may be due to the reason that in $\mathrm{T} 1$ treatment, the growth of the microorganism is suppressed due to the presence of a higher amount of toxic hydrocarbons in absence of the plants that resulted in lower reduction in this treatment $[37,38]$. Relatively higher reduction in hydrocarbons $(56.56 \%)$ was detected in T2 treatment, vegetated with the plant but deprived of bacterial consortium rather than un-vegetated treatment (T1). Due to absorption of easily degradable hydrocarbons in the plant roots, the superior hydrocarbons removal was observed during the initial 30 days of the experiment in T2 treatment. These results are in agreement with the finding of previous research $[39,40]$. The literature study revealed that in spite of microorganisms, the degradation of hydrocarbons is also assisted by plants that play a fundamental role by taking up the hydrocarbons in their roots and shoots and change them into less harmful substances [41,42]. In control without the plant (C), the hydrocarbons content also decreased up to $9.30 \%$ which may be due to evaporation of volatile hydrocarbons present in the diesel oil and/or due to the presence of indigenous bacteria in water or photolysis in the unplanted control [41,43,44].

\subsection{Chemical and Biological Oxygen Demand}

Reduction in COD and BOD is illustrated in Figure 3; Figure 4, respectively. In T3 treatment vegetated with Cyperus laevigatus and bacteria, COD and BOD were reduced up to $52.18 \%$ and $72.28 \%$, respectively. These results are in agreement with our previous findings that growths of plants with bacterial consortium improve the remediation potential of organic components present in wastewater [45]. It is stated that bacterial consortium emulsifies the hydrocarbons in water resulting in lowering of COD and BOD values. Relatively lower reduction in COD (36.61\%) and BOD (56.68\%) was noticed in $\mathrm{T} 2$ treatment. It was described that the higher the number of plants, the more reduction in the COD 
and BOD $[11,26]$. However, relatively minimum reduction of COD $(26.54 \%)$ and BOD $(39.98 \%)$ was observed in T1 treatment. Control exhibited very less reduction in COD (10.33\%) and BOD (12.2\%).

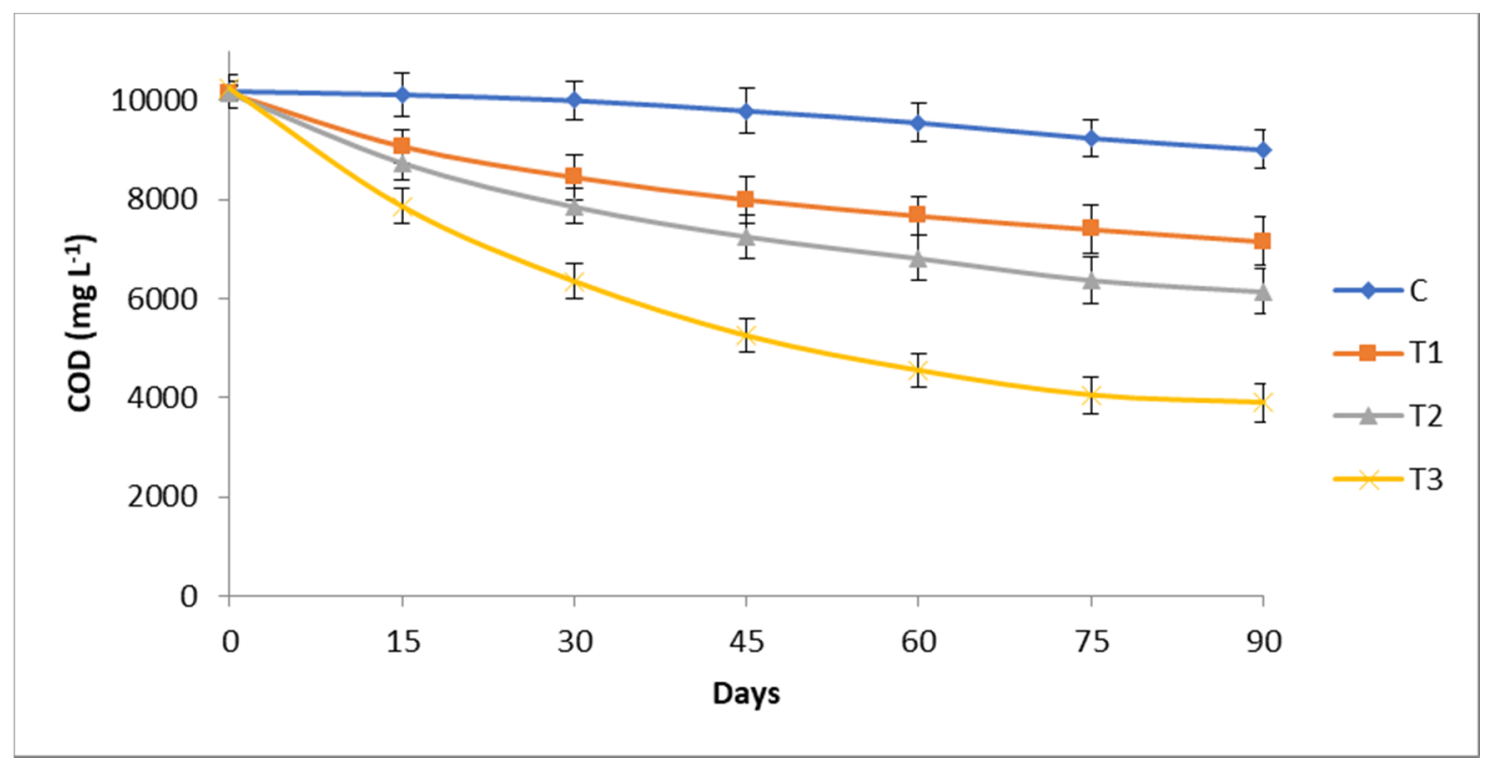

Figure 3. Chemical oxygen demand (COD) removal from water by floating treatment wetlands. C: Microcosm containing diesel oil polluted water and no plants; T1: Microcosm containing diesel oil polluted water and bacterial consortium; T2: Microcosm containing diesel oil polluted water and plants; T3: Microcosm containing diesel oil polluted water, plants and bacterial consortium. Each value is a mean of triplicate determination. Error bars represent the standard deviations among all three replicates.

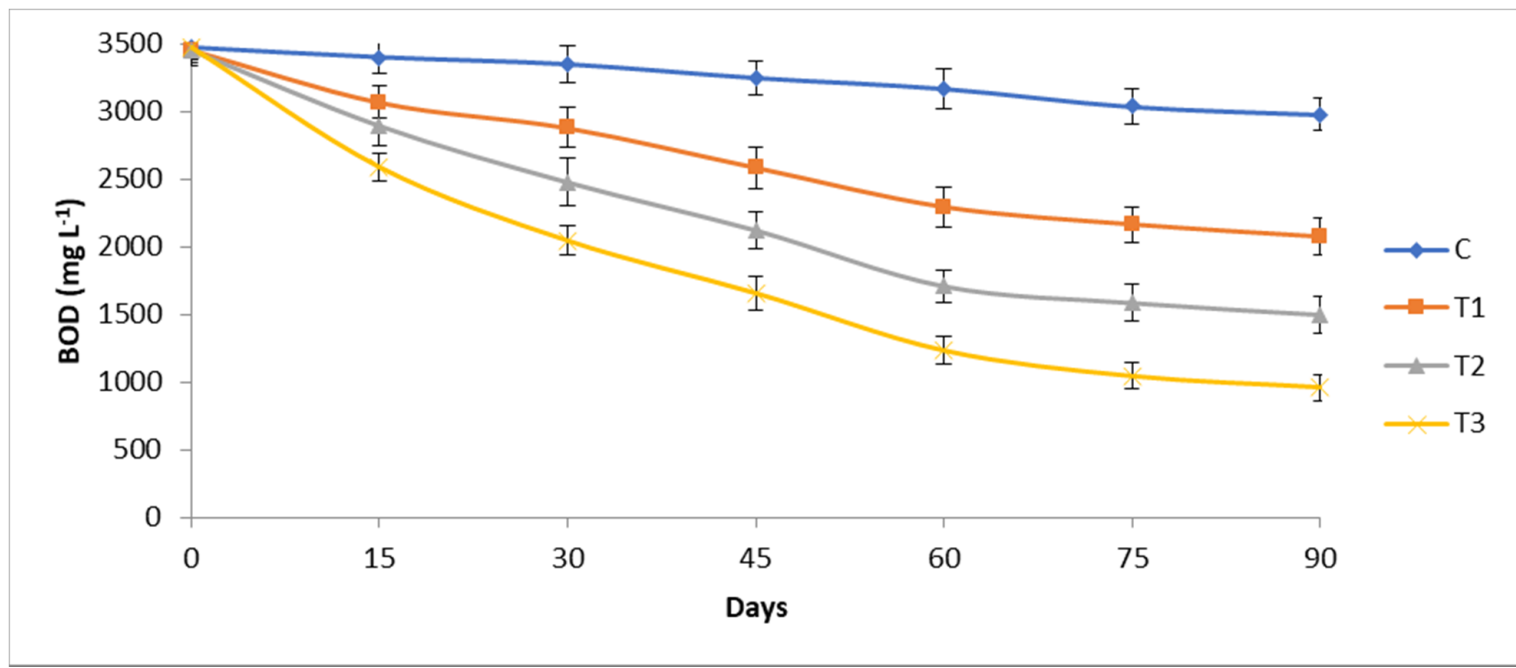

Figure 4. Biochemicalical oxygen demand (BOD) removal from water by floating treatment wetlands. C: Microcosm containing diesel oil polluted water and no plants; T1: Microcosm containing diesel oil polluted water and bacterial consortium; T2: Microcosm containing diesel oil polluted water and plants; T3: Microcosm containing diesel oil polluted water, plants and bacterial consortium. Each value is a mean of triplicate determination. Error bars represent the standard deviations among all three replicates.

\subsection{Total Organic Carbon and Phenol Reduction}

Total organic carbon (TOC) reduction is shown in Figure 5. Higher TOC reduction (91.71\%) was observed in T3 treatment as compared to T2 treatment that exhibited lower TOC reduction (76.96\%). 
However, minimum TOC reduction $(67.70 \%)$ was recorded in $\mathrm{T} 1$ treatment among all the treatments. Non-significant results for TOC reduction (17.36\%) were seen in control. It has been revealed that the growth of plants by utilizing the organic matter as a source of nutrients is supported by the cluster of microbes availability in the plants roots, which is the main reason for the higher reduction in TOC $[46,47]$.

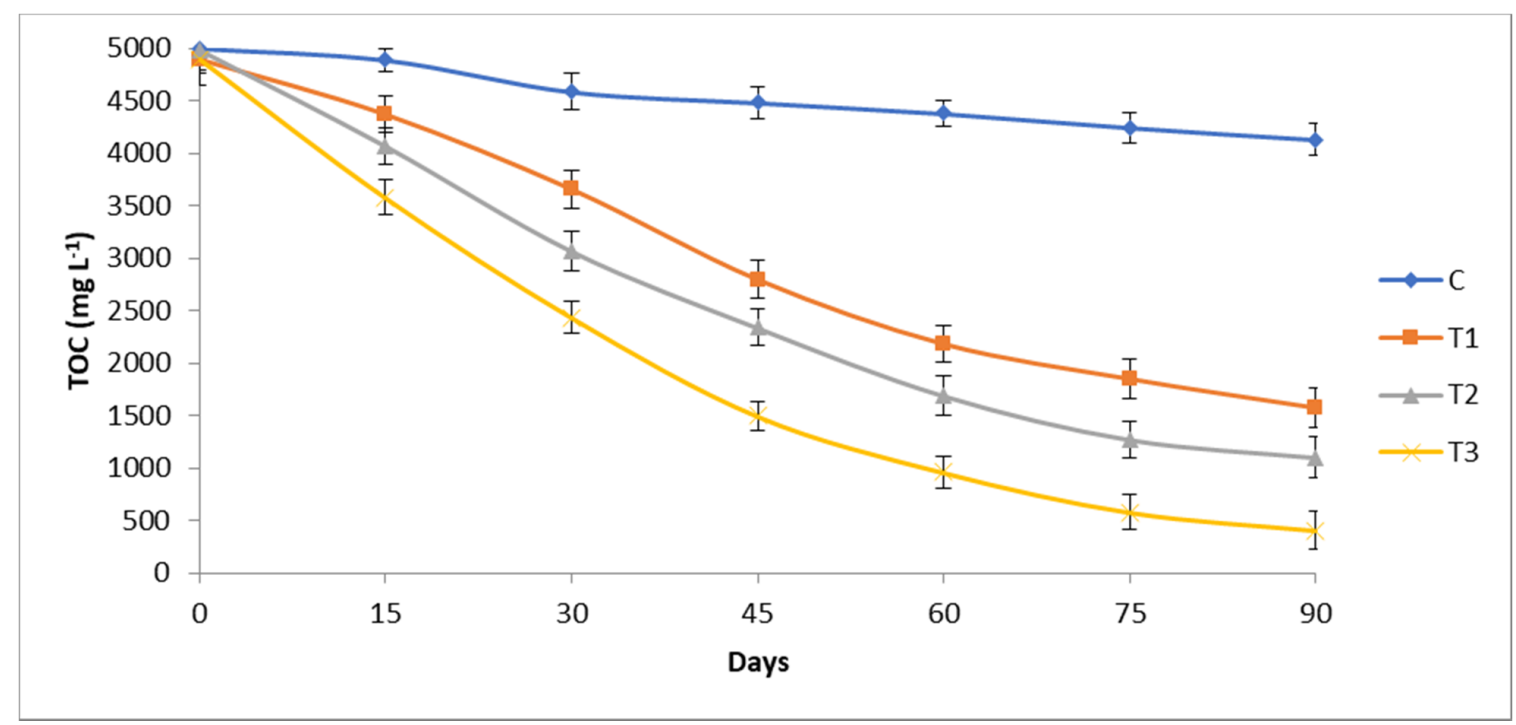

Figure 5. Total organic carbon (TOC) removal from water by floating treatment wetlands. C: Microcosm containing diesel oil polluted water and no plants; T1: Microcosm containing diesel oil polluted water and bacterial consortium; T2: Microcosm containing diesel oil polluted water and plants; T3: Microcosm containing diesel oil polluted water, plants and bacterial consortium. Each value is a mean of triplicate determination. Error bars represent the standard deviations among all three replicates.

Higher reduction (94.88\%) in phenol was examined in T3 treatment, which is significant as compared to other treatments (T1 and T2). It was also observed that effective reduction $(93.44 \%)$ in phenol was seen in T2 treatment. However, lower removal of phenol $(77.14 \%)$ was detected in the treatment T1 (Table 1). Our results are in agreement with the earlier study who reported the effectiveness of bacterial augmentation in phenol removal [48].

\subsection{Removal of Solids}

Table 1 illustrates the removal of solids from diesel oil contaminated water. Consequently, highest reduction occurred in TS $(52.19 \%)$, TSS $(75.56 \%)$, TDS $(49.63 \%)$, and EC $(74.09 \%)$ in bacterially-augmented treatment (T3). Apparently, it was observed that the FTWs showed efficiency to improve the quality of water by reducing the $\mathrm{pH}$ value that ranged from 8.5 to 7.5 , which is authenticated by previous findings [45,49]. It was observed that due the presence of the Cyperus laevigatus plant in T2 treatment, in comparison to T1 treatment (without plants), higher concentrations of nutrients were removed from the wastewater. This finding was within the permissible range reported earlier [50]. 
Table 1. Inoculation bacterial effect on remediation of diesel oil polluted water in floating treatment wetlands microcosms vegetated with Cyperus laevigatus L.

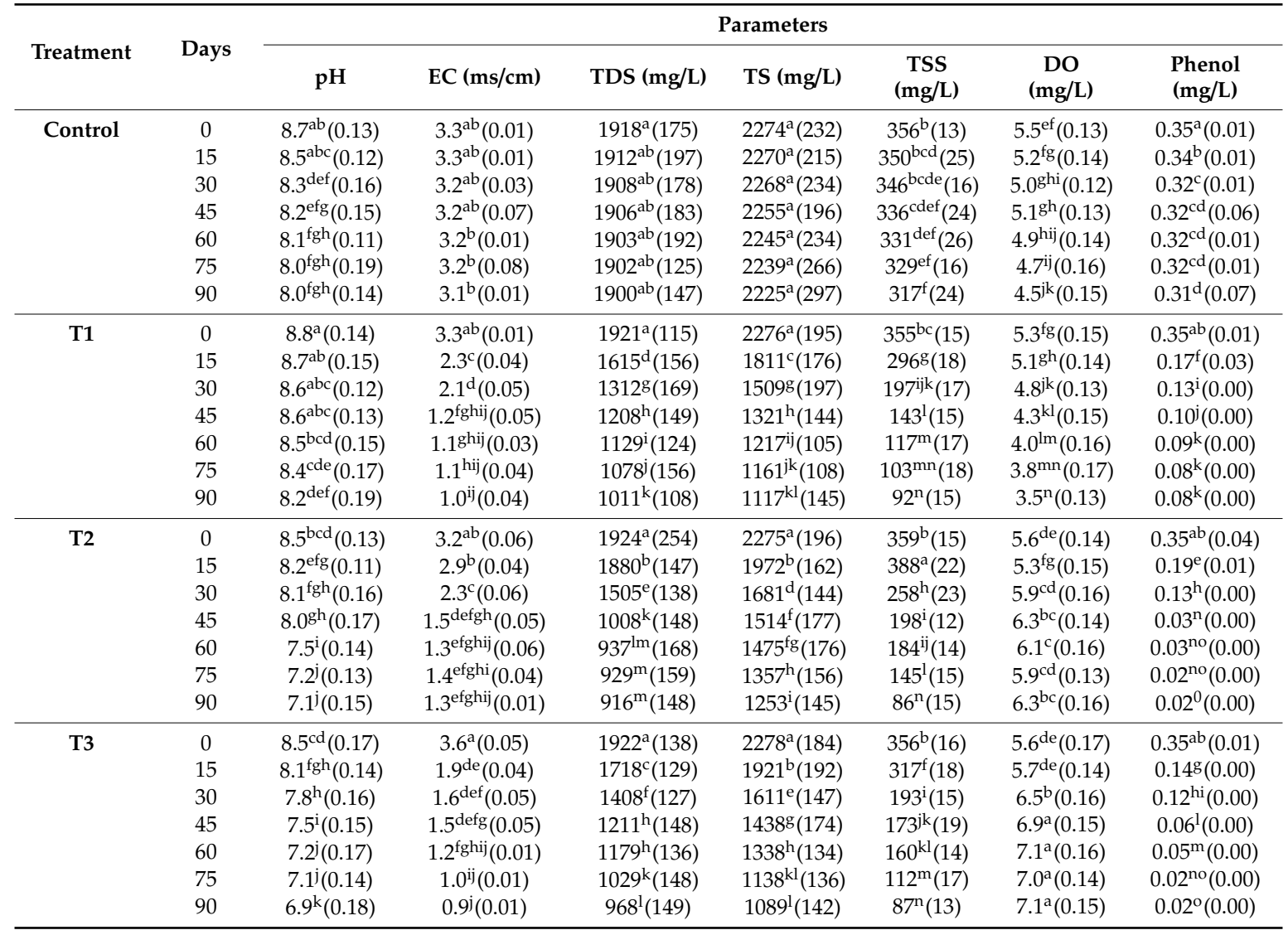

Control: Microcosm containing diesel oil polluted water and no plants; T1: Microcosm containing diesel oil polluted water and bacterial consortium; T2: Microcosm having diesel oil polluted water and plants; T3: Microcosm having diesel oil polluted water, plants and bacterial consortium. Each value is a mean of triplicate determination. Standard deviations among three replicates are presented in parenthesis and the alphabets represent the significant/non-significant difference among the treatments.

\subsection{Persistence of Microbial Population}

Mostly plant-associated microbes mineralize the organic pollutants. It has been explored that the effectiveness of the FTWs technique is truly related to the biodegradation of organic pollutants and persistence of inoculated bacterial in the water investigated for remediation [49,51]. Persistence of bacterial population in the root interior, shoot interior, water, and in the rhizoplane is shown in Table 2. Higher level of bacterial colonization in the plant roots and shoots and also in hydrocarbon contaminated water was observed in this study. The greater number of survival of inoculated bacteria $\left(1.01 \times 10^{6} \mathrm{cfu} / \mathrm{mL}\right)$ was recorded after 90 days of the experiment in the treated water. In different plant compartments, bacterial survival follows the order as: rhizoplane $\left(4.5 \times 10^{6}\right)>\operatorname{root}$ interior $\left(4.0 \times 10^{6}\right)$ $>$ shoot interior $\left(1.2 \times 10^{6}\right)$. Higher numbers of bacterial populations were counted in the T3 treatment; it was due to the efficient plant bacterial partnership. As reported by the previous study that plant roots provide residency and nutrients for proliferation of bacterial community present in outer and inner part of the tissues of the plant [52]. It has also been reported that rhizo bacteria that are involved in plant growth are probably to be present in inner tissue of plant (endophyte bacteria) at particular phase of their lifecycle so microbes can effectively penetrate in exposed plant parts especially in root and process of colonization of bacteria occurs by a dynamic mechanism for pollutant removal $[23,53]$. 
Table 2. Enumeration of total microbial loads in the water and tissues of Cyperus laevigatus L augmented with bacterial consortium (T3) during different sampling time.

\begin{tabular}{|c|c|c|c|c|c|c|c|}
\hline \multirow{2}{*}{ Treatments } & \multicolumn{7}{|c|}{$\mathrm{Cfu} \times 10^{5}$} \\
\hline & $0 \mathrm{~d}$ & $15 \mathrm{~d}$ & $30 \mathrm{~d}$ & $45 \mathrm{~d}$ & $60 \mathrm{~d}$ & $75 \mathrm{~d}$ & $90 \mathrm{~d}$ \\
\hline Water $(\mathrm{Cfu} / \mathrm{mL})$ & $27.8^{f}(1.5)$ & $26.3^{\mathrm{h}}(1.3)$ & $17.8^{\mathrm{j}}(0.9)$ & $16.5^{\mathrm{k}}(1.8)$ & $14.4^{1}(1.6)$ & $12.3^{\mathrm{m}}(1.5)$ & $10.1^{\mathrm{o}}(0.8)$ \\
\hline Rhizoplane (Cfu/g) & $8.7 \mathrm{P}(0.8)$ & $12.3^{\mathrm{m}}(1.1)$ & $19.7^{\mathrm{i}}(1.2)$ & $27.5^{\mathrm{fg}}(1.9)$ & $34.2^{\mathrm{d}}(2.1)$ & $39.6^{\mathrm{C}}(2.4)$ & $45.8^{\mathrm{a}}(2.7)$ \\
\hline $\operatorname{Root}(\mathrm{Cfu} / \mathrm{g})$ & $0.4^{\mathrm{v}}(0.05)$ & $5.4^{\mathrm{s}}(1.5)$ & $11.7^{\mathrm{n}}(1.8)$ & $19.9^{\mathrm{i}}(1.5)$ & $27.3^{g}(1.3)$ & $33.8^{\mathrm{e}}(1.4)$ & $40.5^{\mathrm{b}}(1.3)$ \\
\hline Shoot (Cfu/g) & $0.1^{\mathrm{v}}(0.01)$ & $1.2^{\mathrm{u}}(1.4)$ & $3.5^{\mathrm{t}}(0.1)$ & $5.9^{r}(0.3)$ & $7.09(1.1)$ & $9.8^{\circ}(1.3)$ & $12.3^{\mathrm{m}}(1.6)$ \\
\hline
\end{tabular}

Each value is a mean of triplicate determination. Standard deviations amongst three replicates are existing in parenthesis and the alphabets represent the significant/non-significant difference among the treatments.

It has now recently demonstrated that growth of microbial population in roots and shoots of plants and decrease of their survival in water is due to presence of enormous amount of carbon in hydrocarbons contaminated water that provides a source of energy during the microbial proliferation [54].

\subsection{Plant Height and Biomass}

Effectiveness of phytoremediation is of great importance and correlated with selection of a particular plant species, their survival and tolerance in hydrocarbons contaminated water. Due to different interaction of roots of the plants with hydrocarbons, the contaminants are absorbed and transported in the shoot of plants, ultimately affecting the growth and biomass of plants. Roots of plants offer a large surface area for microbial population and act as a modified place for every microbe endorsing the constant source of nutrients [55]. To check the effect of bacterial inoculation for hydrocarbon degradation and growth of the Cyperus laevigatus L plant, both fresh and dry biomass of this plant were recorded (Table 3). In FTWs, Cyperus laevigatus L planted in microcosms that contain diesel oil (T2) displayed lesser root length (54.14\%), shoot length $(49.11 \%)$, fresh $(61.77 \%)$, and dry $(77.06 \%)$, biomasses in comparison to the plants that were vegetated in tap water (Control 2). It has been reported by earlier studies that hydrocarbon pollution significantly affected the growth of plants during rhizoremediation of petroleum hydrocarbons [56,57].

Table 3. Inoculated bacterial effect on biomass, root length, and shoot length of Cyperus laevigatus in using floating treatment wetlands.

\begin{tabular}{ccccccc}
\hline \multirow{2}{*}{ Treatments } & \multicolumn{2}{c}{ Fresh Biomass $(\mathbf{g})$} & \multicolumn{2}{c}{ Dry Biomass $(g)$} & \multicolumn{2}{c}{ Length (cm) } \\
\cline { 2 - 6 } & Root & Shoot & Root & Shoot & Root & Shoot \\
\hline C2 & $302^{\mathrm{b}}(7.6)$ & $454^{\mathrm{a}}(33.7)$ & $191^{\mathrm{b}}(7.8)$ & $306^{\mathrm{a}}(11.8)$ & $31.4^{\mathrm{c}}(1.1)$ & $56.2^{\mathrm{a}}(2.1)$ \\
T2 & $91^{\mathrm{f}}(3.8)$ & $198^{\mathrm{d}}(6.3)$ & $46^{\mathrm{f}}(1.3)$ & $68^{\mathrm{e}}(3.1)$ & $14.4^{\mathrm{f}}(0.8)$ & $28.6^{\mathrm{d}}(1.8)$ \\
T3 & $109^{\mathrm{e}}(6.7)$ & $218^{\mathrm{c}}(13.8)$ & $78^{\mathrm{d}}(4.9)$ & $93^{\mathrm{c}}(4.2)$ & $18.5^{\mathrm{e}}(1.2)$ & $34.9^{\mathrm{b}}(2.2)$ \\
\hline
\end{tabular}

C2: Microcosm containing tap water and plants; T2: Microcosm containing diesel oil polluted water and plants; T3: Microcosm containing diesel oil polluted water, plants and bacterial consortium. All value is a mean of triplicate determination. Standard deviation among three replicates is existing in parenthesis and the alphabets represent the significant/non-significant difference among the treatments.

It has been proposed that by the absorption of toxic hydrocarbons by plants, the reduction occurs in uptake of water and growth of plants, which are ascribed to chlorosis, oxygen depletion, and dryness in vegetated plants $[49,58]$. However, the treatment containing Cyperus laevigatus L and bacterial consortium (T3) exhibited lesser root length (41.08\%), shoot length (37.90\%), fresh biomass (56.74\%), and dry biomass $(65.59 \%)$ in the context of the control irrigated with tap water.

It has been described earlier that specific bacteria, especially those involved in hydrocarbon degradation, have the capability to decrease the toxicity of organic pollutant in hydrocarbons contaminated water, which is directly attributed to effective growth of plants and their biomass [59]. Existence of plant growth stimulating and hydrocarbons degrading bacteria, exist interior and exterior 
of the plant tissues, emulsify the hydrocarbons, and make their availability easy for bacteria to degrade them into compounds that can be utilized by the plants, ultimately diminishing the toxic effect of hydrocarbons for better growth and biomass production of plants $[60,61]$.

\subsection{Reduction of Toxicity}

After the completion of the experiment, the level of remediation of hydrocarbons was further confirmed by the exposure of fish to treated water (Table 4). Fish toxicity testing was performed in order to evaluate the effectiveness of FTWs in improving water quality to a level that also becomes safe for living organisms. In the FTWs system, the treated water with Cyperus laevigatus L and the bacterial consortium (T3) showed less toxification. In treated water of T3 treatment, only two fish died out of 10 exposed to hydrocarbon contaminated water.

Table 4. Evaluation of toxicity of diesel oil contaminated water detoxified by floating treatment wetlands.

\begin{tabular}{|c|c|c|c|c|c|c|}
\hline \multirow{2}{*}{ Treatments } & \multicolumn{4}{|c|}{ Fish Death Time } & \multirow{2}{*}{ Total Death } & \multirow{2}{*}{ Detoxification Position } \\
\hline & $24 \mathrm{~h}$ & $48 \mathrm{~h}$ & $72 \mathrm{~h}$ & $96 \mathrm{~h}$ & & \\
\hline Control & 10 & 0 & 0 & 0 & $10 / 10^{\mathrm{a}}$ & Negligible \\
\hline $\mathrm{T} 1$ & 2 & 1 & 1 & 1 & $5 / 10^{\mathrm{b}}$ & Partial \\
\hline $\mathrm{T} 2$ & 1 & 1 & 1 & 1 & $3 / 10^{c}$ & Partial \\
\hline T3 & 1 & 1 & 0 & 0 & $2 / 10^{\mathrm{d}}$ & Complete \\
\hline
\end{tabular}

Control: Microcosm containing diesel oil contaminated water and no plants; T1: Microcosm containing diesel oil polluted water and bacterial consortium; T2: Microcosm containing diesel oil contaminated water and plants; T3: Microcosm containing diesel oil polluted water and bacterial consortium. The alphabets represent the significant/non-significant difference among the treatments.

For assessment of toxicity level among different treatments, it was observed that T1 and T2 treatments exhibited death of 5 and 3 fish out of 10 fish, respectively; nevertheless, after $24 \mathrm{~h}$ duration, fish were entirely dead in the control. The survival of fish in T2 and T3 treatments indicated the detoxification and pollutant reduction in the hydrocarbon contaminated wastewater. Besides, it was observed that presence of hydrocarbon degrading bacterial strains in FTWs excellently assisted in enhancement of water quality and decrease in toxicity of the contaminated water. Similar investigations have been reported in earlier studies that combined use of plant and bacteria is a more active methodology in the detoxification of the polluted water than individual use of plant and bacteria $[30,62]$. Due to the presence of a higher concentration of hydrocarbons in the control, oxidative stress increased which resulted in chronic cellular DNA damage, so a number of fish died in the untreated wastewater [63].

\section{Conclusions}

The FTWs augmented with bacteria is proven efficient among all the phytoremediation techniques. Hydrocarbons degrading bacterial strains and the Cyperus laevigatus L plant improved the diesel oil remediation in FTWs. This study investigates and justifies a way to remediate the diesel oil pollution in water. Cyperus laevigatus L plant can be the appropriate choice in FTWs for phytoremediation of diesel oil contaminated water. The performance and effectiveness of the developed FTWs were proven by successful reduction in hydrocarbons, COD, BOD, and TOC of diesel oil contaminated water. Though the experiment was completed in FTWs consisting of a microcosm set up, it displayed an effective bacterial association together with wetland plants. The study highlights a very supportable application of FTWs for conceivable removal of hydrocarbons from contaminated wastewater. This study further offers the prospects of evaluating the effectiveness of FTWs and is a promising option in the wastewater treatment at pilot and field scale levels. Furthermore, FTWs technology involves natural ways of treating wastewater and minimum energy is required for its operational cost. Application of this FTWs technology in developing countries like Pakistan is more feasible and cost effective in contrast to expensive technologies used for wastewater treatment worldwide. 
Author Contributions: Conceptualization, M.F., S.A., S.R.A., M.A. (Muhammad Afzal), M.A. (Muhammad Arslan), E.F.A.A., M.N.A. and P.A.; Data curation, M.F., G.S. and M.A. (Muhammad Afzal); Formal analysis, M.F., G.S., S.R.A., T.Y., A.H. (Afzal Hussain) and M.A. (Muhammad Afzal); Funding acquisition, M.A. (Muhammad Afzal), A.H. (Abeer Hashem), E.F.A.A. and P.A.; Investigation, S.A., S.R.A., M.A. (Muhammad Arslan), M.N.A. and P.A.; Methodology, M.F., T.Y., A.H. (Abeer Hashem), A.H. (Afzal Hussain) and P.A.; Project administration, S.A., T.Y. and E.F.A.A.; Resources, M.A. (Muhammad Afzal), M.A. (Muhammad Arslan), A.H.(Abeer Hashem), E.F.A.A., M.N.A. and P.A.; Software, G.S. and A.H. (Afzal Hussain); Supervision, S.A., T.Y. and M.A. (Muhammad Afzal); Validation, G.S.; Visualization, M.N.A.; Writing—original draft, M.F.; Writing-review \& editing, S.A., S.R.A., M.A. (Muhammad Afzal) and M.A. (Muhammad Arslan). All authors have read and agreed to the published version of the manuscript.

Funding: This research was supported by the Higher Education Commission, Pakistan (grant number 20-3854/R\&D/HEC/14). The authors would like to extend their sincere appreciation to the Researchers Supporting Project Number (RSP-2019/116), King Saud University, Riyadh, Saudi Arabia.

Acknowledgments: This research was supported by the Higher Education Commission, Pakistan (grant number 20-3854/R\&D/HEC/14). The authors would like to extend their sincere appreciation to the Researchers Supporting Project Number (RSP-2019/116), King Saud University, Riyadh, Saudi Arabia.

Conflicts of Interest: The authors declare no conflicts of interest.

\section{References}

1. Li, H.; Hao, H.; Yang, X.; Xiang, L.; Zhao, F.; Jiang, H.; He, Z. Purification of refinery wastewater by different perennial grasses growing in a floating bed. J. Plant Nutr. 2012, 35, 93-110. [CrossRef]

2. Tony, M.A.; Purcell, P.J.; Zhao, Y. Oil refinery wastewater treatment using physicochemical, Fenton and Photo-Fenton oxidation processes. J. Environ. Sci. Health 2012, 47, 435-440. [CrossRef]

3. Daflon, S.D.A.; Guerra, I.L.; Reynier, M.V.; Botta, C.R.; Campos, J.C. Toxicity identification and evaluation of a refinery wastewater from Brazil (Phase I). Ecotoxicol. Environ. Contam. 2015, 10, 41-45. [CrossRef]

4. Shahriari, T.; Karbassi, A.; Reyhani, M. Treatment of oil refinery wastewater by electrocoagulation-flocculation (Case Study: Shazand Oil Refinery of Arak). Int. J. Environ. Sci. Technol. 2018, 16, 4159-4166. [CrossRef]

5. Hernández-Francisco, E.; Peral, J.; Blanco-Jerez, L. Removal of phenolic compounds from oil refinery wastewater by electrocoagulation and Fenton/photo-Fenton processes. J. Water Proc. Eng. 2017, 19, 96-100. [CrossRef]

6. Agarry, S.E.; Oghenejoboh, K.M.; Latinwo, G.K.; Owabor, C.N. Biotreatment of petroleum refinery wastewater in vertical surface-flow constructed wetland vegetated with Eichhornia crassipes: Lab-scale experimental and kinetic modelling. Environ. Technol. 2018, 1-21. [CrossRef]

7. Mandri, T.; Lin, J. Isolation and characterization of engine oil degrading indigenous microrganisms in Kwazulu-Natal, South Africa. Afr. J. Biotechnol. 2007, 7, 1927-1932.

8. Mustapha, H.I.; Van Bruggen, J.; Lens, P. Vertical subsurface flow constructed wetlands for polishing secondary Kaduna refinery wastewater in Nigeria. Ecol. Eng. 2015, 84, 588-595. [CrossRef]

9. Fakhru'l-Razi, A.; Pendashteh, A.; Abdullah, L.C.; Biak, D.R.A.; Madaeni, S.S.; Abidin, Z.Z. Review of technologies for oil and gas produced water treatment. J. Hazard. Mater. 2009, 170, 530-551. [CrossRef]

10. Chen, Z.; Reiche, N.; Vymazal, J.; Kuschk, P. Treatment of water contaminated by volatile organic compounds in hydroponic root mats. Ecol. Eng. 2017, 98, 339-345. [CrossRef]

11. Shahid, M.J.; Arslan, M.; Siddique, M.; Ali, S.; Tahseen, R.; Afzal, M. Potentialities of floating wetlands for the treatment of polluted water of river Ravi, Pakistan. Ecol. Eng. 2019, 133, 167-176. [CrossRef]

12. Tara, N.; Arslan, M.; Hussain, Z.; Iqbal, M.; Khan, Q.M.; Afzal, M. On-site performance of floating treatment wetland macrocosms augmented with dye-degrading bacteria for the remediation of textile industry wastewater. J. Clean. Prod. 2019, 217, 541-548. [CrossRef]

13. Chen, Z.; Kuschk, P.; Reiche, N.; Borsdorf, H.; Kästner, M.; Köser, H. Comparative evaluation of pilot scale horizontal subsurface-flow constructed wetlands and plant root mats for treating groundwater contaminated with benzene and MTBE. J. Hazard. Mater. 2012, 209, 510-515. [CrossRef] [PubMed]

14. Wang, C.-Y.; Sample, D.J. Assessment of the nutrient removal effectiveness of floating treatment wetlands applied to urban retention ponds. J. Environ. Manag. 2014, 137, 23-35. [CrossRef] [PubMed]

15. Headley, T.R.; Tanner, C.C. Constructed wetlands with floating emergent macrophytes: An innovative stormwater treatment technology. Crit. Rev. Environ. Sci. Technol. 2012, 42, 2261-2310. [CrossRef] 
16. Tanner, C.C.; Headley, T.R. Components of floating emergent macrophyte treatment wetlands influencing removal of stormwater pollutants. Ecol. Eng. 2011, 37, 474-486. [CrossRef]

17. Chen, Z.; Cuervo, D.P.; Müller, J.A.; Wiessner, A.; Köser, H.; Vymazal, J.; Kästner, M.; Kuschk, P. Hydroponic root mats for wastewater treatment-A review. Environ. Sci. Pollut. Res. 2016, 23, 15911-15928. [CrossRef]

18. Faulwetter, J.; Burr, M.D.; Cunningham, A.B.; Stewart, F.M.; Camper, A.K.; Stein, O.R. Floating treatment wetlands for domestic wastewater treatment. Water Sci. Technol. 2011, 64, 2089-2095. [CrossRef]

19. Ghosh, A.; Dastidar, M.G.; Sreekrishnan, T. Bioremediation of Chromium Complex Dye by Growing Aspergillus flavus. In Water Quality Management; Springer: New York, NY, USA, 2018; pp. 81-92.

20. Sessitsch, A.; Mitter, B.; Compant, S.; Trognitz, F.; Brader, G. The plant microbiome: Ecology and functioning of bacterial endophytes and how plants can benefit. In Proceedings of the EGU General Assembly Conference Abstracts, Vienna, Austria, 8-13 April 2018; p. 2201.

21. Gomes, M.; Gonzales-Limache, E.; Sousa, S.; Dellagnezze, B.; Sartoratto, A.; Silva, L.; Gieg, L.; Valoni, E.; Souza, R.; Torres, A. Exploring the potential of halophilic bacteria from oil terminal environments for biosurfactant production and hydrocarbon degradation under high-salinity conditions. Int. Biodeterior. Biodegrad. 2018, 126, 231-242. [CrossRef]

22. Lopes, P.R.M.; Montagnolli, R.N.; Cruz, J.M.; Claro, E.M.T.; Bidoia, E.D. Biosurfactants in Improving Bioremediation Effectiveness in Environmental Contamination by Hydrocarbons. In Microbial Action on Hydrocarbons; Springer: New York, NY, USA, 2018; pp. 21-34.

23. Afzal, M.; Khan, Q.M.; Sessitsch, A. Endophytic bacteria: Prospects and applications for the phytoremediation of organic pollutants. Chemosphere 2014, 117, 232-242. [CrossRef]

24. Fatima, K.; Afzal, M.; Imran, A.; Khan, Q.M. Bacterial rhizosphere and endosphere populations associated with grasses and trees to be used for phytoremediation of crude oil contaminated soil. Bull. Environ. Contam. Toxicol. 2015, 94, 314-320. [CrossRef]

25. Arslan, M.; Afzal, M.; Amin, I.; Iqbal, S.; Khan, Q.M. Nutrients can enhance the abundance and expression of alkane hydroxylase CYP153 gene in the rhizosphere of ryegrass planted in hydrocarbon-polluted soil. PLoS ONE 2014, 9, e111208. [CrossRef]

26. Rehman, K.; Imran, A.; Amin, I.; Afzal, M. Enhancement of oil field-produced wastewater remediation by bacterially-augmented floating treatment wetlands. Chemosphere 2019, 217, 576-583. [CrossRef] [PubMed]

27. APHA; AWWA; WEF. Standard Methods for the Examination of Water and Wastewater; American Public Health Association: Washington, DC, USA, 2012.

28. Afzal, M.; Yousaf, S.; Reichenauer, T.G.; Sessitsch, A. The inoculation method affects colonization and performance of bacterial inoculant strains in the phytoremediation of soil contaminated with diesel oil. Int. J. Phytoremediat. 2012, 14, 35-47. [CrossRef] [PubMed]

29. Shahid, M.J.; Tahseen, R.; Siddique, M.; Ali, S.; Iqbal, S.; Afzal, M. Remediation of polluted river water by floating treatment wetlands. Water Supply 2019, 19, 967-977. [CrossRef]

30. Shehzadi, M.; Afzal, M.; Khan, M.U.; Islam, E.; Mobin, A.; Anwar, S.; Khan, Q.M. Enhanced degradation of textile effluent in constructed wetland system using Typha domingensis and textile effluent-degrading endophytic bacteria. Water Res. 2014, 58, 152-159. [CrossRef] [PubMed]

31. Geetha, S.; Banat, I.M.; Joshi, S.J. Biosurfactants: Production and potential applications in microbial enhanced oil recovery (MEOR). Biocatal. Agric. Biotechnol. 2018, 14, 23-32.

32. Varjani, S.J.; Joshi, R.R.; Kumar, P.S.; Srivastava, V.K.; Kumar, V.; Banerjee, C.; Kumar, R.P. Polycyclic aromatic hydrocarbons from petroleum oil industry activities: Effect on human health and their biodegradation. In Waste Bioremediation; Springer: New York, NY, USA, 2018; pp. 185-199.

33. Jambon, I.; Thijs, S.; Weyens, N.; Vangronsveld, J. Harnessing plant-bacteria-fungi interactions to improve plant growth and degradation of organic pollutants. J. Plant Interact. 2018, 13, 119-130. [CrossRef]

34. Singh, P.; Borthakur, A. A review on biodegradation and photocatalytic degradation of organic pollutants: A bibliometric and comparative analysis. J. Clean. Prod. 2018, 196, 1669-1680. [CrossRef]

35. Turkovskaya, O.; Muratova, A. Plant-Bacterial Degradation of Polyaromatic Hydrocarbons in the Rhizosphere. Trends Biotechnol. 2019, 37, 926-930. [CrossRef]

36. Kumari, S.; Regar, R.K.; Manickam, N. Improved polycyclic aromatic hydrocarbon degradation in a crude oil by individual and a consortium of bacteria. Bioresour. Technol. 2018, 254, 174-179. [CrossRef] [PubMed] 
37. Zhang, L.; Zhao, J.; Cui, N.; Dai, Y.; Kong, L.; Wu, J.; Cheng, S. Enhancing the water purification efficiency of a floating treatment wetland using a biofilm carrier. Environ. Sci. Pollut. Res. 2016, 23, 7437-7443. [CrossRef] [PubMed]

38. Adeboye, P.T.; Bettiga, M.; Olsson, L. The chemical nature of phenolic compounds determines their toxicity and induces distinct physiological responses in Saccharomyces cerevisiae in lignocellulose hydrolysates. Amb Express 2014, 4, 46. [CrossRef]

39. Dhote, M.; Kumar, A.; Jajoo, A.; Juwarkar, A. Assessment of hydrocarbon degradation potentials in a plant-microbe interaction system with oil sludge contamination: A sustainable solution. Int. J. Phytoremediat. 2017, 19, 1085-1092. [CrossRef]

40. Pawlik, M.; Cania, B.; Thijs, S.; Vangronsveld, J.; Piotrowska-Seget, Z. Hydrocarbon degradation potential and plant growth-promoting activity of culturable endophytic bacteria of Lotus corniculatus and Oenothera biennis from a long-term polluted site. Environ. Sci. Pollut. Res. 2017, 24, 19640-19652. [CrossRef]

41. Kösesakal, T.; Ünal, M.; Kulen, O.; Memon, A.; Yüksel, B. Phytoremediation of petroleum hydrocarbons by using a freshwater fern species Azolla filiculoides Lam. Int. J. Phytoremediat. 2016, 18, 467-476. [CrossRef]

42. Darajeh, N.; Idris, A.; Truong, P.; Abdul Aziz, A.; Abu Bakar, R.; Che Man, H. Phytoremediation potential of vetiver system technology for improving the quality of palm oil mill effluent. Adv. Mater. Sci. Eng. 2014, 2014. [CrossRef]

43. Zhang, C.-B.; Liu, W.-L.; Pan, X.-C.; Guan, M.; Liu, S.-Y.; Ge, Y.; Chang, J. Comparison of effects of plant and biofilm bacterial community parameters on removal performances of pollutants in floating island systems. Ecol. Eng. 2014, 73, 58-63. [CrossRef]

44. Mitter, E.K.; Kataoka, R.; de Freitas, J.R.; Germida, J.J. Potential use of endophytic root bacteria and host plants to degrade hydrocarbons. Int. J. Phytoremediat. 2019, 21, 928-938. [CrossRef]

45. Rehman, K.; Imran, A.; Amin, I.; Afzal, M. Inoculation with bacteria in floating treatment wetlands positively modulates the phytoremediation of oil field wastewater. J. Hazard. Mater. 2018, 349, 242-251. [CrossRef]

46. Ye, C.; Chen, D.; Hall, S.J.; Pan, S.; Yan, X.; Bai, T.; Guo, H.; Zhang, Y.; Bai, Y.; Hu, S. Reconciling multiple impacts of nitrogen enrichment on soil carbon: Plant, microbial and geochemical controls. Ecol. Lett. 2018, 21, 1162-1173. [CrossRef]

47. Wang, X.; Tang, C.; Severi, J.; Butterly, C.R.; Baldock, J.A. Rhizosphere priming effect on soil organic carbon decomposition under plant species differing in soil acidification and root exudation. New Phytol. 2016, 211, 864-873. [CrossRef]

48. Saleem, H.; Rehman, K.; Arslan, M.; Afzal, M. Enhanced degradation of phenol in floating treatment wetlands by plant-bacterial synergism. Int. J. Phytoremediat. 2018, 20, 692-698. [CrossRef]

49. Ijaz, A.; Imran, A.; ul Haq, M.A.; Khan, Q.M.; Afzal, M. Phytoremediation: Recent advances in plant-endophytic synergistic interactions. Plant Soil 2016, 405, 179-195. [CrossRef]

50. Cui, L.; Ouyang, Y.; Lou, Q.; Yang, F.; Chen, Y.; Zhu, W.; Luo, S. Removal of nutrients from wastewater with Canna indica L. under different vertical-flow constructed wetland conditions. Ecol. Eng. 2016, 36, 1083-1088. [CrossRef]

51. Bordoloi, N.; Konwar, B. Bacterial biosurfactant in enhancing solubility and metabolism of petroleum hydrocarbons. J. Hazard. Mater. 2009, 170, 495-505. [CrossRef]

52. Ijaz, A.; Iqbal, Z.; Afzal, M. Remediation of sewage and industrial effluent using bacterially assisted floating treatment wetlands vegetated with Typha domingensis. Water Sci. Technol. 2016, 74, 2192-2201. [CrossRef]

53. Saxena, G.; Purchase, D.; Mulla, S.I.; Saratale, G.D.; Bharagava, R.N. Phytoremediation of heavy metal-contaminated sites: Eco-environmental concerns, field studies, sustainability issues, and future prospects. Rev. Environ. Contam. Toxicol. 2019, 249, 71-131.

54. Pal, S.; Kundu, A.; Banerjee, T.D.; Mohapatra, B.; Roy, A.; Manna, R.; Sar, P.; Kazy, S.K. Genome analysis of crude oil degrading Franconibacter pulveris strain DJ34 revealed its genetic basis for hydrocarbon degradation and survival in oil contaminated environment. Genomics 2017, 109, 374-382. [CrossRef]

55. Stottmeister, U.; Wießner, A.; Kuschk, P.; Kappelmeyer, U.; Kästner, M.; Bederski, O.; Müller, R.; Moormann, H. Effects of plants and microorganisms in constructed wetlands for wastewater treatment. Biotechnol. Adv. 2003, 22, 93-117. [CrossRef]

56. Hussain, Z.; Arslan, M.; Malik, M.H.; Mohsin, M.; Iqbal, S.; Afzal, M. Integrated perspectives on the use of bacterial endophytes in horizontal flow constructed wetlands for the treatment of liquid textile effluent: Phytoremediation advances in the field. J. Environ. Manag. 2018, 224, 387-395. [CrossRef] 
57. Zhou, W.; Yang, J.; Lou, L.; Zhu, L. Solubilization properties of polycyclic aromatic hydrocarbons by saponin, a plant-derived biosurfactant. Environ. Pollut. 2011, 159, 1198-1204. [CrossRef] [PubMed]

58. Gogosz, A.; Bona, C.; Santos, G.; Botosso, P. Germination and initial growth of Campomanesia xanthocarpa O. Berg.(Myrtaceae), in petroleum-contaminated soil and bioremediated soil. Braz. J. Biol 2010, 70, 977-986. [CrossRef] [PubMed]

59. Afzal, M.; Yousaf, S.; Reichenauer, T.G.; Sessitsch, A. Ecology of Alkane-Degrading Bacteria and Their Interaction with the Plant. Mol. Microb. Ecol. Rhizosphere 2013, 975-989. [CrossRef]

60. Weyens, N.; van der Lelie, D.; Taghavi, S.; Vangronsveld, J. Phytoremediation: Plant-endophyte partnerships take the challenge. Curr. Opin. Biotechnol. 2009, 20, 248-254. [CrossRef]

61. Mesa, V.; Navazas, A.; González-Gil, R.; González, A.; Weyens, N.; Lauga, B.; Gallego, J.L.R.; Sánchez, J.; Peláez, A.I. Use of endophytic and rhizosphere bacteria to improve phytoremediation of arsenic-contaminated industrial soils by autochthonous Betula celtiberica. Appl. Environ. Microbiol. 2017. [CrossRef]

62. Ijaz, A.; Shabir, G.; Khan, Q.M.; Afzal, M. Enhanced remediation of sewage effluent by endophyte-assisted floating treatment wetlands. Ecol. Eng. 2015, 84, 58-66. [CrossRef]

63. Bai, H.; Wu, M.; Zhang, H.; Tang, G. Chronic polycyclic aromatic hydrocarbon exposure causes DNA damage and genomic instability in lung epithelial cells. Oncotarget 2017, 8, 79034. [CrossRef] [PubMed]

(C) 2020 by the authors. Licensee MDPI, Basel, Switzerland. This article is an open access article distributed under the terms and conditions of the Creative Commons Attribution (CC BY) license (http://creativecommons.org/licenses/by/4.0/). 